"Przegląd Prawa Konstytucyjnego" Nr $3(15) / 2013$

\title{
Recenzja
}

\section{Tomasz Bojarowicz, Partie i ugrupowania prawicowe w Polsce po 1989 roku, Wydawnictwo Adam Marszałek, Toruń 2013, ss. 402}

Pojęcie "prawicy politycznej” jest trudne do zdefiniowania, ponieważ jego zakres przedmiotowy wykracza poza kilka jasno określonych kategorii, a często się zdarza, że pod tym określeniem rozumie się koncepcje ideowe w wielu miejscach ze sobą rozbieżne. Widoczne jest to zwłaszcza w Polsce i dotyczy przede wszystkim problemów ekonomicznych i społecznych, głównie zaś stosunku do ingerencji państwowej w gospodarkę i kwestie socjalne. Istnieją bowiem ugrupowania prawicowe żądające ograniczenia w jak największym stopniu działalności państwa w powyższe sfery, ale też można spotkać partie polityczne, również odwołujące się do prawicowej tradycji, według których instytucje państwowe powinny wziąć na siebie obowiązek troski o najbiedniejszych i niezaradnych poprzez różne formy aktywności społeczno-ekonomicznej. Innym rozróżnieniem dzielącym prawą stronę sceny politycznej jest stosunek do religii i narodu. Obok ugrupowań stojących na gruncie zapewnienia katolicyzmowi, czy szerzej chrześcijaństwu, nadrzędnej roli w życiu społecznym oraz traktujących naród jako najwyższą wartość doczesną istnieją także takie, które dążą do rozdziału Kościoła od państwa i integracji międzynarodowej. Trudność definicyjna sprawia więc, że niejednokrotnie ciężko zaliczyć daną partię czy prezentowany program polityczny jednoznacznie do określonej ideologii prawicowej czy lewicowej. Stąd też pojawiają się różne nazewnictwa w postaci centroprawicy, prawicy czy też skrajnej prawicy, jak również nieokreślone hybrydy, łączące w sobie ideologię prawicową z elementami lewicowymi. Niezależnie jednak od stopnia trudności w określeniu, czym jest współczesna prawica, warto przyjrzeć się temu zagadnieniu i je bliżej zanalizować. 
Zadania tego podjął się Tomasz Bojarowicz w monografii Partie i ugrupowania prawicowe w Polsce po 1989 roku. Nie jest to pierwsza pozycja, dotycząca współczesnych polskich ugrupowań prawicowych, która ukazała się w III Rzeczypospolitej. W ciągu ostatnich kilkunastu lat pojawiły się bowiem na rynku wydawniczym monografie dotyczące ruchu konserwatywnego (Konrad Wandowicz, Współczesny konserwatyzm polityczny w Polsce (1989-1998), Wrocław 2000), chrześcijańsko-demokratycznego (Paweł Łyżwa, Myśl chrześcijańskiej demokracji w III RP, Toruń 2003), narodowego (Czesław i Ewa Maj, Narodowe ugrupowanie polityczne w Polsce 1989-2001, Lublin 2007) i liberalnego (Polskie ugrupowania liberalne, red. Łukasz Tomczak, Wrocław 2010). Ukazały się również pozycje dotyczące konkretnych partii prawicowych - Platformy Obywatelskiej (Platforma Obywatelska, red. Marek Migalski, Toruń 2009) oraz Prawa i Sprawiedliwości (Prawo i Sprawiedliwość, red. Marek Migalski, Toruń 2010). Na uwagę zasługują również publikacje dotyczące współczesnej polskiej myśli politycznej, obejmujące myśl polityczną zaliczaną do ideologii prawicowych (Współczesna polska myśl polityczna, red. Bronisław Pasierb, Krystyna Anna Paszkiewicz, Wrocław 1996; Myśl polityczna w Polsce po 1989 roku: Wybrane nurty ideowe, red. Ewa Maj, Alicja Wójcik, Lublin 2008 oraz Religia, polityka, naród. Studia nad współczesna myśla polityczną, red. Rafał Łętocha, Kraków 2010), jak również monografie, charakteryzujące współczesną polską scenę polityczną (Andrzej Antoszewski, Ryszard Herbut, Wiesław Jednaka, Partie i system partyjny w Polsce. Pierwsza faza przejścia ku demokracji, Wrocław 1993; Andrzej Antoszewski, Polska scena polityczna - system czy chaos?, Bydgoszcz 2002; POPiSy w polityce: Uwagi o polskiej scenie politycznej, red. Maciej Drzonek, Janusz Mieczkowski oraz Partie i system partyjny RP. Stan i perspektywy, red. Krzysztof Kowalczyk, Łukasz Tomczak, Toruń 2007). Są to jednak publikacje albo wycinkowe, dotyczące konkretnej prawicowej ideologii lub partii politycznej, albo zbiory syntetyczne dotyczące wszystkich nurtów i ugrupowań istniejących w III Rzeczypospolitej. Żadna jednak nie podejmuje konkretnego zagadnienia, dotyczącego kwestii, czym jest i czym się charakteryzuje prawica w Polsce.

Recenzowana pozycja aspiruje do roli pierwszej syntetycznej monografii, omawiającej całościowo polskie ugrupowania polityczne należące do ideologii prawicowej. Świadczy o tym jej zakres czasowy i problemowy. Omawia- 
ny okres obejmuje lata od 1989 r., uważanego za koniec Polski Ludowej, do roku 2011, czyli ostatnich jak dotychczas wyborów parlamentarnych. Żadna z wymienionych pozycji nie ma tak rozległego temporalnie zakresu, który analizuje niemal cały dotychczasowy okres III RP. Pierwsza cezura w pewnych miejscach została przesunięta wstecz, kiedy autor wyjaśniał genezę niektórych ugrupowań, mających swoje początki w okresie PRL (jak Konfederacja Polski Niepodległej czy Unia Polityki Realnej) lub też nawiązujących w swojej działalności do ugrupowań okresu międzywojennego i lat II wojny światowej (np. Stronnictwo Narodowe i Stronnictwo Pracy). Zakres problemowy obejmuje natomiast wszystkie należące do nurtu prawicowego partie polityczne, działające na polskiej scenie politycznej, ewolucję prawej strony sceny politycznej, główne podstawy ideologiczne tych ugrupowań oraz ich wpływy w społeczeństwie, mierzone wynikami wyborczymi.

Monografia ma strukturę problemową i składa się z czterech rozdziałów. W pierwszym, zatytułowanym Istota „prawicy” - kwestie definicyjne - autor podjął się wyjaśnienia pojęcia "prawicy politycznej” poprzez przytoczenie szeregu kategorii określających tę część sceny politycznej oraz wykazanie, co różni prawicę od lewicy i w jakich aspektach te ideologie mogą się przenikać. W rozdziale drugim pod tytułem Geneza partii i ugrupowań prawicowych w Polsce po 1989 roku T. Bojarowicz zaprezentował przyczyny odradzania się polskiej prawicy po upadku PRL, jej inspiracje ideowe, a także ewolucję i przemiany po prawej stronie polskiej sceny politycznej w latach 1989-2010. Rozdział trzeci, Podstawy tożsamości ideowej współczesnej prawicy w Polsce, przybliża główne nurty polskiej prawicy istniejące w III RP wraz z ich głównymi cechami charakterystycznymi, a także stosunek polskiej prawicy do głównych problemów wewnętrznych i zagranicznych Rzeczypospolitej Polskiej. Natomiast rozdział czwarty, Udział partii i ugrupowań prawicowych $w$ rywalizacji politycznej, opisuje wpływy polskich partii prawicowych na podstawie wyborów parlamentarnych, samorządowych i prezydenckich, a także ich udział w koalicjach rządowych i opozycji parlamentarnej.

Autor, zdając sobie sprawę $\mathrm{z}$ trudności w jednoznacznym zdefiniowaniu pojęcia „prawica”, przyjął kilka kryteriów, które uznał za wyznaczniki tej ideologii we współczesnym polskim systemie politycznym. Zaznaczył jednocześnie, że niektóre $\mathrm{z}$ nich nie występują $\mathrm{w}$ zachodnim rozumieniu tego pojęcia, tylko stanowią polską specyfikę tej strony sceny politycznej. Wśród 
głównych kryteriów polskiej prawicy zostały wyszczególnione: 1) aprobata dla hierarchii społecznej, 2) tradycjonalizm, 3) szacunek dla osoby ludzkiej, 4) idea silnego państwa, opartego na autorytecie prawa, 5) antykomunizm oraz postulaty dekomunizacji i lustracji, 6) akcentowanie wartości chrześcijańskich, 7) akcentowanie wartości narodowych, 8) elementy lewicowości w kwestiach społeczno-gospodarczych. Porównując programy partii prawicowych w Polsce z ideologią na zachodzie Europy i w Stanach Zjednoczonych, T. Bojarowski doszedł do wniosku, że wśród konstytutywnych wyznaczników polskiej prawicy zabrakło postulatów ograniczonego interwencjonizmu państwowego w kwestiach społeczno-ekonomicznych, natomiast pojawił się nieznany w tamtych państwach, ale wynikający z polskiej historii, czynnik antykomunistyczny. Przyjęcie tych kryteriów pozwala obserwatorom życia politycznego w Polsce na bardziej analityczne i wnikliwe rozpatrywanie poszczególnych ugrupowań pod kątem ideowym i programowym, a także w dużej mierze systematyzuje polską scenę polityczną.

Walorem monografii, oprócz przedstawienia cech charakterystycznych polskiej prawicy, jest również wyszczególnienie jej nurtów, które chociaż odwołują się do powyższych kryteriów, różnią się między sobą. Autor wyszczególnił siedem głównych nurtów po prawej stronie sceny politycznej: 1) chrześcijańsko-demokratyczny, 2) liberalny, 3) konserwatywny, 4) narodowo-katolicki, 5) niepodległościowy, 6) prawicy modernistycznej oraz 7) tradycjonalistyczno-etatystyczny. Każdy z nich został scharakteryzowany pod względem cech szczegółowych i wyznawanych wartości. Jednocześnie, opierając się na założeniach ideowych, T. Bojarowicz dał liczne przykłady ugrupowań, które można zaliczyć do każdego z tych nurtów. Do pierwszego z nich zaliczył Partię Chrześcijańskich Demokratów, Chrześcijańsko-Demokratyczne Stronnictwo Pracy oraz Porozumienie Centrum, do drugiego Kongres Liberalno-Demokratyczny, do trzeciego - Partię Konserwatywną, Unię Polityki Realnej, Stronnictwo Konserwatywno-Ludowe i Ruch Stu, do czwartego - Stronnictwo Narodowe i Ligę Polskich Rodzin, do piątego Konfederację Polski Niepodległej, Ruch Odbudowy Polski, Ruch dla Rzeczypospolitej i Ruch Katolicko-Narodowy, do szóstego - Platformę Obywatelską, zaś do siódmego - Zjednoczenie Chrześcijańsko-Narodowe oraz Prawo i Sprawiedliwość. Pozwala to na zorientowanie się w różnorodności ugrupowań prawicowych w III RP i przypisaniu ich do jednego z tych nurtów. Trze- 
ba zauważyć, że autor dostrzegał też elementy prawicowej myśli w ugrupowaniach niezaliczanych do tej ideologii, czyli Unii Demokratycznej i Unii Wolności.

Inną zaletą recenzowanej pozycji jest przedstawienie ewolucji polskiej sceny politycznej po prawej jej stronie od momentu wyborów czerwcowych 1989 r. W sytuacji, kiedy w pierwszej połowie lat 90. powstawały liczne ugrupowania, które po pewnym czasie zmieniały nazwy, dzieliły się, przekształcały w nowe formacje lub stawały się częścią większych całości uchwycenie przez przeciętnego obserwatora reprezentowanych przez nie kierunków ideowych jest niezmiernie trudne. Autorowi jednak udało się nie tylko w sposób przystępny przedstawić te procesy w przypadku prawicy, ale również wyjaśnić, czemu tak się działo, co było przyczyną tak dużego rozdrobnienia partii prawicowych w tym czasie i dlaczego w późniejszym okresie doszło do konsolidacji mniejszych ugrupowań w silne i duże stronnictwa. Każda partia prawicowa została również pokrótce scharakteryzowana pod względem personalnym i ideologicznym, chociaż więcej miejsca poświęcono, oczywiście, tym ugrupowaniom, które chociaż raz znalazły się w parlamencie po 1989 r., przedstawiając również ich działalność na forum Sejmu i w koalicji rządowej.

Wśród walorów należy również wymienić próbę autora zmierzenia się z problemem, jakim były w omawianym okresie wpływy partii prawicowych w polskim społeczeństwie. T. Bojarowicz zaprezentował to poprzez omówienie wyborów parlamentarnych, samorządowych i prezydenckich, w których starał się nakreślić zarówno sytuację przedwyborczą, przebieg kampanii wyborczej, jak i wyniki. Jednocześnie w pewnym stopniu zaprezentował udział i pozycję poszczególnych partii prawicowych w rządach III RP (od gabinetu Jana Krzysztofa Bieleckiego po pierwszy gabinet Donalda Tuska) oraz stanowisko prawicy w roli opozycji względem rządów lewicowych lub rządów $\mathrm{z}$ udziałem innych partii prawicowych.

Monografia, mimo niewątpliwych zalet, ma jednak pewne niedostatki. O ile pierwsze dwa rozdziały w sposób wyczerpujący omawiają zasygnalizowane w tytułach treści, o tyle dwa kolejne wymagają uzupełnień. W rozdziale trzecim, w części dotyczącej problematyki wewnętrznej, zabrakło omówienia wizji ustroju politycznego państwa polskiego, jakie prezentowały ugrupowania prawicowe, zaś koncepcje gospodarcze obejmują jedynie okres 
pierwszej dekady III RP. Najwięcej braków ma jednak rozdział czwarty, dotyczący wpływów politycznych polskiej prawicy. Przede wszystkim w wynikach wyborów parlamentarnych zabrakło szczegółowych wyników wszystkich ugrupowań prawicowych biorących udział w poszczególnych elekcjach do Sejmu (liczba głosów, procent oddanych głosów, ewentualna liczba mandatów). Zazwyczaj autor podawał tylko wyniki najważniejszych ugrupowań, a i to nie zawsze (np. w latach 1991, 2001, 2005). Zabrakło też przedstawienia wyników wyborczych do Senatu. Odnośnie do wyborów samorządowych to jako wadę można uznać brak szczegółowego omówienia wyników prawicowych partii politycznych do sejmików wojewódzkich, zwłaszcza od 1998 r., kiedy sejmiki zaczęły być wybierane w głosowaniu powszechnym. Zważywszy na to, że sejmik jest jednym z dwóch organów samorządu, w którym toczy się walka partyjna (obok rad miejskich głównych miast Polski), to brak danych ze wszystkich województw odnośnie do wyników ugrupowań prawicowych nie pozwala na pełne przedstawienie wpływów prawicy w Polsce. Są to jednak braki, które można uzupełnić przy następnej edycji tej publikacji.

Monografia Tomasza Bojarowicza stanowi znaczące osiągnięcie w polskiej literaturze naukowej ze względu na swoją tematykę, która jest nowa i porusza istotne zagadnienia dla każdego obserwatora polskiej sceny politycznej. Dzięki niej czytelnik może usystematyzować swoją wiedzę na temat prawicy w III RP, jej głównych nurtów oraz reprezentujących je ugrupowań. Oparta na szerokiej bazie źródłowej stanowi cenny wkład w badanie polskiego systemu partyjnego i polskiej współczesnej myśli politycznej, a jej braki i niedociągnięcia mogą być inspiracją dla samego autora czy innych badaczy do poszerzenia jej o niezbędne treści.

Tomasz Koziełło Uniwersytet Rzeszowski 